\title{
Barns med- og selvbestemmelsesrett - etter ulike lover
}

Barns med- og selvbestemmelsesrett har vært tema flere ganger i FAB, ofte rettet inn mot helsespørsmål. ${ }^{1}$ På dette området foreligger nå viktige lovendringsforslag som skal presenteres og vurderes. Samtidig gis en oppdatert oversikt over hvordan aldersgrenser kommer til uttrykk i ulike lover, og bakgrunnen for vedtatte regelendringer.

Det er rimelig med en slik oppdatering nå som barns rett til å bli hørt og deres rett til medbestemmelse er nedfelt i Grl. § 104, noe som allerede er vektlagt i flere høyesterettsavgjørelser. ${ }^{2}$

Et greit utgangspunkt er at ulike lover opererer med ulike «aldersgrenser» og/eller «myndighetsaldre». Men det er ikke alltid klart hva en lovfestet aldersgrense egentlig innebærer. Illustrerende eksempler kan være seksuell lavalder, retten til å bestemme over egne opptjente midler, retten til å nekte medisinsk behandling, til religiøs «frigjøring», til utdanningsvalg mv. Det er tallrike slike bestemmelser og ikke alltid lett å se om det er sammenheng mellom disse.

De aktuelle bestemmelsene i barneloven, som må oppfattes som lex generalis, vokste fram på grunnlag av tidligere vergemålslov og de to tidligere barnelovene. Ikke minst bidro Barnelovutvalget med en framsynt utredning i NOU 1977: 35 Lov om barn og foreldre som la grunnlaget for barnelova (bl.), lov 8. april $1981 \mathrm{nr}$. 7, som ennå gjelder.

I dag ville nok lovteksten i større grad tatt utgangspunkt i barnet som et selvstendig rettssubjekt, men da sett i sammenheng med reglene om foreldreansvaret og foreldres vergerolle i økonomiske spørsmål.

Samordningen av regler om aldersgrenser utfordres ved at disse utarbeides av minst fem departementer: ${ }^{3}$ Barne- og likestillingsdepartementet (BLD) har det politiske ansvaret for barnelova, barnevernloven, ekteskapsloven og diskrimineringslovgivningen. Justis- og beredskapsdepartementet (JD) har et tilsvarende ansvar for blant annet Grunnloven, vergemålsloven,

\footnotetext{
${ }^{1}$ Se for eksempel Henriette Sinding Aasen: Barns rett til selvbestemmelse og medbestemmelse i beslutninger om helsehjelp, FAB 2008, s. 4-28.

${ }^{2}$ Et nytt, sterkt eksempel er den enstemmige kjennelsen 4. januar 2017 (HR-2017-18-U) der Høyesteretts ankeutvalg opphevet lagmannsrettens beslutning om å nekte anke om et barns bosted fordi barnet ikke var hørt. ${ }^{3}$ Da er ikke medtatt Samferdselsdepartementet med sine ulike aldersgrenser for utstedelse av førerkort, Medietilsynets aldersgrenser for kino, DVD mv. og tilsvarende regelverk litt på siden av FABs interessefelt.
} 
forvaltningsloven, skadeserstatningsloven, arvelova og utlendingsloven, mens Kunnskapsdepartementet (KD) håndterer opplæringslova, barnehageloven, voksenopplæringsloven, friskolelova mv. Helse- og omsorgsdepartementet (HOD) har ansvaret for pasient- og brukerrettighetsloven (pbrl.), helsepersonelloven og mange helselover med ulike aldersgrenser, mens Arbeidsog sosialdepartementet (ASD) har ansvaret for blant annet folketrygdloven, arbeidsmiljøloven, sosialtjenesteloven og trygderettsloven.

Departementene er ikke nevnt i en tilfeldig rekkefølge. Etter min vurdering avspeiler denne rekkefølgen departementenes engasjement i spørsmålet om mindreåriges rettigheter. ASD nevner i sosialtjenesteloven knapt ordet «barn» i loven eller tilhørende forskrifter og rundskriv, selv om arbeidsmiljøloven kap. 11 inneholder strenge regler om begrensning av barnearbeid med aldersgrenser på respektive 13, 14, 15 og 18 år.

HOD har til nå stått for det grelleste eksemplet ved bestemmelsen i pbrl. § 3-1 (2) med ordlyden: «Barn under 18 år skal tas med på råd når barnets utvikling og modning og sakens art tilsier det.» Bestemmelsen var ille nok, men konteksten gjør den enda verre idet den gjelder pasients og brukers rett til medvirkning. Bestemmelsen var ny så sent som i 2011 og trådte i kraft fra 2012. Den måtte i realiteten bortfortolkes som en «inkurie» $\mathrm{i}$ en lov som parallelt opererer med 12-årsgrense for retten til å bli hørt før foreldre gir samtykke til helsehjelp (pbrl. § 4-4), og bestemmelsen er nå foreslått opphevd. ${ }^{4}$

Skadeserstatningsloven (skl.) kap.1 har regler om barns erstatningsansvar og om foreldres erstatningsansvar for barns skadevoldende handlinger. Det er også egne regler om barns eget medvirkningsansvar, som etter skl. § 5-1 først inntrer ved fylte 10 år.

De ulike bestemmelsene i Grl. § 104 beskytter barns rettigheter på tilsvarende måte som reglene i barnelova og barnevernloven. Verken i Grunnloven eller de sentrale barnelovene er det lenger en nedre grense for retten til å bli hørt. Etter Barnekonvensjonen (BK) art. 1 er barn definert som personer under 18 år, og etter forarbeidene er det rimelig å legge samme aldersgrense til grunn for forståelsen av Grl. § 104.

\footnotetext{
4 Prop. 75 L (2016-2017) Endringar i pasient- og brukarrettslova, helsepersonellova m.m. (styrking av rettsstillinga til barn ved yting av helse-og omsorgstenester m.m.).
} 
Forarbeidene til den nye Grl. § 104 bidrar riktignok lite til å klargjøre når barns medvirkningsrett skal gå over i bestemmelsesrett, noe heller ikke Barnekonvensjonen gjør. I Dok. 16 (2011-2012) uttales på s. 191:

Formuleringer av barns medbestemmelsesrett kan ta utgangspunkt i barnets rett til å bli hørt og barnets rett til å øve innflytelse på de beslutninger som gjelder barnet selv. Den innflytelsen barnet har over beslutningene, vil deretter måtte avhenge av barnets alder og utvikling. Ungdom som nærmer seg 18 år, skal normalt ha større innflytelse på beslutninger enn for eksempel 7 -åringer. [...]

Utvalget finner at en grunnlovsbestemmelse om barns rettigheter bør inkludere en formulering om at barn har rett til å bli hørt, og at de bør ha rett til å øve innflytelse på beslutninger som gjelder dem selv.

I det videre skal nevnes de viktigste initiativene som har ført fram til dagens regler om barns med- og selvbestemmelsesrett, basert på forslag fra (minst) tre ulike regjeringer. Barnelovutvalgets utredning dannet som nevnt grunnlaget for Ot.prp. nr. 62 (1979-80) med forslag til ny barnelov.

Vel 20 år senere ble BK inkorporert i menneskerettsloven ved endringslov 1. aug. $2003 \mathrm{nr}$. 86. Parallelt ble det foretatt endringer i bl. § 31 ved endringslov 20. juni 2003 nr. 40 (i kraft 2004). Viktige endringer fulgte så ved vedtakelsen av vergemålsloven (lov 26. mars $2010 \mathrm{nr}$. 9) og gjennom ikrafttredelsesloven for samme. Endelig skal nevnes endringslov 21. juni $2013 \mathrm{nr}$. 62 som hadde et hovedfokus på barneperspektivet i foreldretvister.

Da barneloven ble forberedt, forelå en 12-årsregel for barns uttalerett i personlige forhold i (tidl.) vergemålslov § 40. Både Barnelovutvalget og regjeringens oppfølgende lovforslag ville senke denne til en 7-årsgrense («normal skolealder»). Forslaget møtte motbør i Stortingets justiskomité som i Innst. O. nr. 30 (1980-81) på s. 8 var «prinsipielt enig» i at barnet tidlig bør få medbestemmelsesrett. Men forslaget til bl. § 31 (1) ble endret fra 7 år-med en noe påfallende begrunnelse - at endringen ville kunne få en «større holdningsskapende virkning i positiv retning når den ikke var knyttet til en bestemt aldersgrense». Samtidig ble det tydeliggjort i bl. § 31 (2) at barn på 12 år skulle høres før avgjørelser i personlige spørsmål, og at barnets mening skulle tillegges «stor vekt».

Gjennom de to lovendringene i 2003, se ovenfor, ble grensen i bl. § 31 (2) for barns rett til å bli hørt senket til en 7-årsgrense. Ved inkorporeringen av BK i menneskerettsloven ble det samtidig vedtatt endringer i blant annet 
forvaltningsloven (om uttalerett for mindreårige), barnevernloven (7-årsgrense for å bli hørt) og adopsjonsloven (7-årsgrense for å bli hørt; etter 12 år krav om barnets samtykke).

I Prop. 46 L (2012-2013) Endringer i vergemålsloven mv. ble det samtidig foreslått (og vedtatt) endringer i blant annet barnelova, adopsjonsloven, ekteskapsloven, pasient- og brukerrettighetsloven, bioteknologiloven, helseforskningsloven og helse- og omsorgstjenesteloven. Gjennomgående ble angivelsen «myndig» erstattet med «etter fylte 18 år», som vel mest kan vurderes som en språklig endring. Det ble videre tydeliggjort i vgml. § 17 (4) et skille i alder for barns rett til å bli hørt i økonomiske spørsmål (12 år) og i personlige spørsmål (7 år og under det). Dette kommer til uttrykk på denne måten i én og samme bestemmelse:

Er den mindreårige over 12 år, skal vergen høre hva den mindreårige mener før det treffes avgjørelser. Om den mindreåriges medbestemmelsesrett i personlige forhold gjelder reglene i barneloven $\S 31$.

En fjerde lovendring i bl. § 31 skjedde ved behandlingen av Prop. 85 L (20122013) Endringer i barnelova (barneperspektivet i foreldretvister). Det ble da tydeliggjort i andre ledd at alle barn har rett til å bli hørt etter hvert som de kan danne seg egne synspunkter, men etter 7 år har de en absolutt rett.

Etter de nevnte lovendringene har bl. § 31 om barns medbestemmelsesrett nå følgende ordlyd:

Etter kvart som barnet blir i stand til å danne seg eigne synspunkt på det saka dreiar seg om, skal foreldra høyre kva barnet har å seie før dei tek avgjerd om personlege forhold for barnet. Dei skal leggje vekt på det barnet meiner alt etter kor gammalt og modent barnet er. Det same gjeld for andre som barnet bur hos eller som har med barnet å gjere.

Eit barn som er fylt sju år, og yngre barn som er i stand til å danne seg eigne synspunkt, skal få informasjon og høve til å seie meininga si før det blir teke avgjerd om personlege forhold for barnet, mellom anna om foreldreansvaret, kvar barnet skal bu fast og samvær. Meininga til barnet skal bli vektlagt etter alder og modning. Når barnet er fylt 12 år, skal det leggjast stor vekt på kva barnet meiner.

Et spennende - og omdiskutert - spørsmål har vært om denne bestemmelsen må anses som generelt virkende og derved «overstyre» lovbestemmelser med høyere aldersgrenser for uttaleretten, som for eksempel helselover med 12årsgrenser. Akkurat dette spørsmålet finner snart sin løsning i de foreslåtte 
lovendringer i pasient- og brukerrettighetsloven mv. som vil føre til tilsvarende bestemmelser om barns uttalerett. ${ }^{5}$

I barnevernloven ble uttalerett uavhengig av alder innført i 2003 ved inkorporeringen av BK. Barns rett til å bli hørt i saker, selv når de er representert ved verge, ble samtidig innført i forvaltningsloven (fvl.), se fvl. § 11d (muntlig høring), § 16 (forhåndsvarsling), § 17 (forvaltningsorganets utrednings- og informasjonsplikt) og $\S 18$ (partenes adgang til å gjøre seg kjent med sakens dokumenter).

Viktige drøftinger om barns medvirkningsrett fant også sted forut for lovendringen i barnevernlovens medvirkningsbestemmelse (bvl. § 4-1), se nærmere Prop. 106 L (2012-2013), og dette spørsmålet ble grundig behandlet i det forutgående høringsnotatet. ${ }^{6}$ Endringen førte i og for seg ikke til endring i aldersgrenser, men skulle gi uttrykk for et ønske om å fremme barns rett til deltakelse, medvirkning og medbestemmelse.

Når det gjelder barns selvbestemmelsesrett, var også forslagene fra Barnelovutvalget og JD forut for sin tid. Bl. § 32 ble gitt en ordlyd som er blitt stående uendret:

Barn som er fylt 15 år, avgjer sjølv spørsmål om val av utdanning og om å melde seg inn i eller ut av foreiningar.»

Bestemmelsen i bl. § 32 er ikke uttømmende. Barnet kan også på andre områder gis selvbestemmelsesrett før fylte 18 år, jf. bl. § 33 og særskilte lovbestemmelser, som kirkeloven $\S 3 \mathrm{nr}$. 6 og trossamfunnsloven (lov 13. juni 1969 nr. 25) § 3 som begge følger opp 15-årsgrensen.

Sandberg understreker i Norsk lovkommentar at bestemmelsen ikke må forstås antitetisk slik at foreldrene alltid bestemmer i spørsmål om utdanning og foreninger fram til barnet er 15 år. $^{7}$ For medlemskap i foreninger understrekes dette uttrykkelig i NOU 1977: 35 s. 124. Mindreåriges bestemmelsesrett er videre tydeliggjort i særlige aldersbestemmelser i opplæringslova (oppl.), se for eksempel oppl. § 2-1 tredje ledd, § 2-3a og § 3-1.

\footnotetext{
${ }^{55}$ Se høringsnotat fra HOD dat. 4. oktober 2016. Høringsnotatet fikk alminnelig oppslutning og er fulgt opp i førnevnte Prop. 75 L (2016-2017).

${ }^{6}$ Spørsmålene er behandlet i Prop. 106 L (2012-2013), i et eget kap. 18, hvor det også vises til det nevnte høringsnotatet av 5. september 2012.

${ }^{7}$ Note 81 sjekket 1. mars 2017. - Kirsten Sandbergs noter til barnelova er svært grundige og informative.
} 
Bestemmelsen i bl. § 32 ble fulgt opp i bl. § 33 som fikk den betegnende overskriften «Barnet sin sjølvråderett». Også her foreslo Barnelovutvalget og JD en regel som er blitt stående:

Foreldra skal gje barnet stendig større sjølvråderett med alderen og fram til det fyller 18 år.

Bestemmelsen har stått uendret, men med den nye vergemålsloven ble ordet «myndig» byttet ut med «18 år», som i annen lovgivning.

Nært knyttet til selvbestemmelsesretten er også barns partsrettigheter. I bvl. § 63 andre ledd er det tydeliggjort at i atferdssaker og saker om menneskehandel «skal barnet alltid regnes som part». I andre saker gjelder hovedregelen om at barnet skal ha fylt 15 år og forstå hva saken gjelder.

I sosialtjenesteloven (sotj1.) er barn «bare barn»; det er ingen regler om at de skal høres, selv i saker som angår dem. Det ble for $\varnothing$ vrig i 2015 vedtatt en lovendring i sotjl. § $18 \mathrm{om}$ at det ved vurdering av økonomisk stønad (sosialhjelp) til familier ikke skal «tas hensyn til barns inntekt av arbeid i fritid og skoleferier». Barn skal selv kunne nyte godt av fruktene av eget arbeid, og dette framgår også av vergemålsloven (vgml.) om barns selvbestemmelsesrett $\mathrm{i}$ $\emptyset$ konomiske spørsmål. De aktuelle bestemmelsene er samlet i vgml. kap. 3. Som nevnt inntrer barns rett til å bli hørt i økonomiske forhold først etter fylte 12 år, se vgml. § 17 fjerde ledd.

Etter ekteskapsloven $§ 1 \mathrm{a}$ kan en person under 18 år ikke inngå ekteskap uten samtykke fra dem eller den som har foreldreansvaret, supplert med krav om tillatelse fra Fylkesmannen. Fylkesmannen kan ikke gi tillatelse dersom den som søker, er under 16 år. Denne bestemmelsen, og bestemmelsen i ekteskapsloven $\S$ $1 \mathrm{~b}$ om at ekteskap «skal inngås av egen fri vilje og med eget samtykke», motsvares av straffebudet i strl. 253 rettet mot tvangsekteskap.

Ved inngåelse av ekteskap må altså både foreldre og barn samtykke, og i tillegg skal Fylkesmannen vurdere situasjonen. Det blir en form for «delt kompetanse», noe som innebærer at både foreldre og barn har selvstendig vetorett. Dette gjelder også i navnespørsmål, hvor de(n) som har foreldreansvaret, søker eller gir melding når barnet er under 16 år (senket fra 18 år fra 2016), men barnets samtykke kreves når det er fylt 12 år, se navneloven $\S 12$. Det samme gjelder ved adopsjon, se adopsjonsloven $\S 6$.

I helselovgivningen inntrer selvbestemmelsesretten ved ulike aldre. Hovedregelen finnes i pbrl. § 4-3 som gir barn over 16 år med tilstrekkelig 
forståelse både rett til å samtykke og til å nekte helsehjelp. Dette innebærer også en rett til fravalg av livreddende behandling dersom det ikke foreligger en øyeblikkelig-hjelp-situasjon.

Men det er flere grenser som fører til unntak fra hovedbestemmelsen. Dels kan barn under 16 år samtykke selvstendig dersom barnet, «av grunner som bør respekteres», ikke ønsker at foreldrene skal blandes inn eller høres, se pbrl. § 3-4 første ledd. Tilsvarende bestemmelser er også lovfestet i helseforskningsloven og helseregisterloven.

De fleste særreglene oppstiller høyere aldersgrenser enn 16 år. Det er en normal aldersgrense på 18 år for organdonasjon (transplantasjonslova §7), kjøp av tobakk, $\varnothing \mathrm{log}$ vin, mens kjøp av brennevin krever fylte 20 år (tobakksskadeloven og alkoholloven). Høyeste aldersgrense på 25 år gjelder for steriliseringsinngrep etter egen begjæring, se steriliseringsloven $\S 2$. En grense som ikke er lovfestet, men som er innfortolket ut fra kravene i pbrl. § 4-3 første ledd bokstav b om «tiltakets art», er at en person må være fylt 18 år for å kunne få utført plastikkirurgiske inngrep på kosmetisk indikasjon.

For samtykke til forskning som inkluderer deltakere under 16 år, gjelder samtykkebestemmelsene i pbrl. § 4-4 tilsvarende, se helseforskningsloven § 17 fjerde ledd. Dersom barn mellom 12 og 16 år av grunner som bør respekteres, ikke ønsker at foreldrene, andre med foreldreansvar eller barneverntjenesten gjøres kjent med opplysninger om barnet, skal dette ivaretas.

Det synes for $\varnothing v$ vrig gjennomgående å være slik at barnelovgivningen opererer med en 15-årsgrense for selvstendig kompetanse for den mindreårige, mens den tilsvarende minstealderen i helselovgivningen stort sett er 16 år. Dette gjelder for eksempel for inntak i institusjon basert på eget samtykke, og aldersgrensen varierer derfor avhengig av om den aktuelle institusjonen ligger under barnevernets domene eller under psykisk helsevern. På den andre siden kan barn over 15 år utsettes for tvang etter barnevernlovens bestemmelser, men samtykkekompetente personer (over 16 år) kan ikke pålegges somatiske helsetjenester utover øyeblikkelig hjelp. Det kan utgjøre en relevant forskjell når det gjelder den legislative begrunnelsen.

Ingen helsegrenser når likevel opp mot alderskravet til høyesterettsdommere som etter Grl. § 91 ikke kan beskikkes før «han eller hun er 30 år gammel», noe som vel neppe ville skje selv uten denne bestemmelsen. 
Oppsummeringsmessig synes ulike departementer å ha ulikt syn på betydningen av barns rett til å bli hørt. ASD stiller nederst på rangstigen, mens BLD - ikke uventet - tar disse bestemmelsene mest alvorlig.

I de siste årene synes lovgivningen på feltet å bli mer harmonisert, og nå følger som nevnt HOD opp de alminnelig virkende bestemmelsene på feltet i BK art. 12, Grl. $\S 104$ og bl. § 31. Det er på høy tid. Selv uten lovendringer vil jo barns rett til å bli hørt, uavhengig av alder, følge av BK art. 12 og Grl. § 104, uansett hva den enkelte lov sier (lex superior). Men det er nok pedagogisk viktig - og kanskje nødvendig - at dette tydeliggjøres i den enkelte helselov. Det er langt fra sikkert at alt helsepersonell kjenner til overordnet lovgivning på dette området.

Der lovgivningen oppstiller høyere aldersgrenser enn 16 år for barns rett til selvbestemmelse, synes disse å være legislativt godt begrunnet. Bestemmelser oppstilt til vern om mindreåriges integritet (eksempelvis vern mot barnearbeid, erstatningsansvar, seksuell integritet) og barns rett til å bli hørt går lavere ned i alder enn rettighetsbestemmelser og rett til selvbestemmelse. Etter mitt syn er det gode grunner for dette.

Aslak Syse

Aslak Syse er professor emeritus ved Institutt for offentlig rett, Universitetet i Oslo 